\title{
Relation between blood lipid levels and angiographically evaluated obstructions in coronary arteries
}

\author{
Sigurd Nitter-Hauge and Ivar Enge \\ From Medical Department B and Roentgen Department, University Hospital, Rikshospitalet, Oslo, Norway
}

An analysis has been made of $7 I$ patients studied by selective coronary cine-angiography in whom coronary artery disease was diagnosed on the basis of clinical findings. Forty-six patients had a proven history of previous myocardial infarction, while the remaining 25 patients had angina pectoris without myocardial infarction. The degree of obstruction of all three main coronary arteries, as revealed by the angiograms, has been correlated with the fasting level of serum cholesterol and triglycerides. We were unable to find any significant correlation between the serum lipids and the severity of the obstructive disease. This does not necessarily mean that the blood lipids are of no importance in the development of coronary atherosclerosis. From our study it is evident that in patients with developed coronary artery disease, the role of the serum lipids may be modified to an extent which makes any correlation between lipid levels and the angiographic findings impossible.

Selective cine-angiography today represents a standard method for the assessment of the presence and severity of structural changes in the coronary arteries, and has proved to be a valuable adjunct to the diagnosis and evaluation of atherosclerotic heart disease. Of considerable interest in this connexion are studies designed to evaluate the relation between the severity of atheromatous degeneration and blood lipids. Previous studies in this field have given controversial results. Some investigators state that the incidence of normal coronary arteriograms is higher in subjects whose serum cholesterol is low compared with subjects with raised serum cholesterol (Proudfit, Shirey, and Sones, 1967). However, Cramér, Paulin, and Werkø (1966) found no significant relation between serum cholesterol values and coronary artery changes, while raised triglyceride levels were more common among those with severe coronary atherosclerosis. Eliasch et al. (1967) concluded that neither serum cholesterol nor triglycerides influenced significantly the severity of arterial obstruction. In the studies referred to above, various systems of scoring the structural changes observed on the angiograms were used, and the methods and circumstances in which blood was analysed were also different.

Recently, Banks, Raftery, and Oram (197I) used

Received 5 March 1973. a method of scoring the degree of obstruction in the main coronary arteries as revealed by selective coronary arteriography and then summating the scores. They found a linear relation between the level of serum cholesterol and the severity of structural changes, and that this relation was present even in patients in whom serum cholesterol varied within normal range. Their results have later been commented upon as representing a 'key link' between the blood lipids and the severity of coronary atheromatous disease (Lancet, 197I). To test the validity of this hypothesis, we have reviewed the coronary angiograms from a total of $7 \mathrm{I}$ patients, all suspected on clinical grounds of suffering from coronary artery disease. The extent of the structural changes has been correlated with the serum concentrations of cholesterol and triglycerides.

\section{Subjects and methods}

The study is based on the findings in $7 \mathrm{I}$ patients, referred to our medical department for diagnostic evaluation of their coronary vessels. This series must be regarded as selected, as it contains only patients with well-documented previous history of myocardial infarction or angina pectoris without myocardial infarction. The duration of their symptoms varied from several months to years. The infarction group consisted of 44 men and 2 women (mean age 53.8 years), and the angina pectoris group of 20 men and 5 women (mean age 53.0 years). 
Coronary arteriography was done when surgical procedures to improve the blood supply to ischaemic areas of the myocardium were under consideration.

The patients went through a routine clinical and laboratory examination. Venous blood for lipid studies was drawn in the morning the day after admission, after a I2-hour fast. Total serum cholesterol was determined by the method of Carr and Drekter (1956): normal range, 150 to $300 \mathrm{mg} / 100 \mathrm{ml}$. Triglycerides were determined by a modification described by Laurell (1966): normal range 50 to $150 \mathrm{mg} / 100 \mathrm{ml}$.

Selective coronary cineangiography was carried out according to the technique described by Judkins (I967). The coronary arteriograms were performed in left and right anterior oblique and additional projections when needed. The three main coronary arteries: the anterior descending branch and the circumflex branch of the left coronary artery and the right coronary artery and their tertiary branches were identified and evaluated separately. The coronary arteriograms were reviewed by the authors, one of whom (I. E.) had done most of the radiological examinations and was familiar with the technique. The interpretation and grading of the angiograms were made without knowledge of the blood lipid levels. The structural changes observed on the angiograms were graded according to the classification given by Nordenstrøm (1964), giving each of the three main coronary arteries a score from o to 3: grade o, no structural changes visible; grade I, structural changes with narrowing of less than half the arterial lumen; grade 2, structural changes with narrowing of more than half the arterial lumen or down to $\mathrm{I} \mathrm{mm}$ in diameter; and grade 3, total occlusion of the vessel.

The three scores given were added together to give a total score which represented the overall obstructive disease for all the three arteries of the heart. Thus, the minimum possible total score for each patient was 0 and the maximum was 9. Care was taken to exclude all possibilities of misinterpretation due to anatomical variations and faulty techniques such as poor exposure and inadequate views.

Arithmetical means, standard deviations, and coefficients of correlations were calculated as described by Snedecor (1956). Regression lines were drawn according to equations found by the method of least squares. Statistical significance of differences between means was made using Student's t-test. P values higher than 0.05 were not considered to be significant.

\section{Results}

In those patients with a diagnosis of myocardial infarction mean serum cholesterol was $293.2 \mathrm{mg} / \mathrm{roO}$ $\mathrm{ml}(\mathrm{SD} \pm 63.54)$, versus $328.0 \mathrm{mg} / 100 \mathrm{ml}$ (SD \pm III.37) in the group with angina pectoris. The small difference between the two groups was not significant $(\mathbf{P}>0.05)$. The corresponding mean values for the triglycerides were $141.9 \mathrm{mg} / 100 \mathrm{ml}$ $(\mathrm{SD} \pm 66.39)$ and $150.5 \mathrm{mg} / 100 \mathrm{ml}(\mathrm{SD} \pm 85.68)$, respectively, the mean difference being not significant $(P>0.05)$

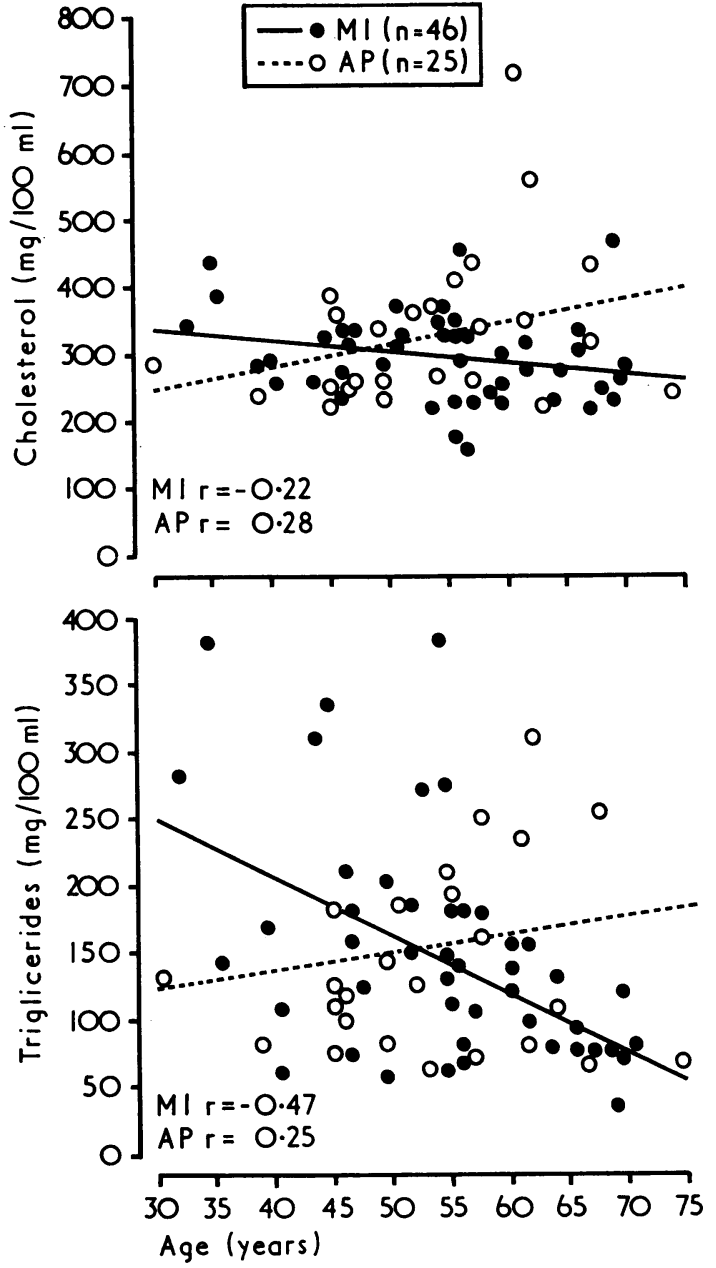

FI G. I The relation between age and serum cholesterol (above) and triglycerides (below). Patients with myocardial infarction and patients with angina pectoris without infarction are separated. The regression lines for each group are shown.

A combination of normal serum cholesterol and triglycerides as well was found in 31 patients, while raised values for both parameters were present in 20 patients. In the remainder, either cholesterol or triglycerides varied within normal range, leaving the other raised.

There was no significant relation between serum cholesterol and age, either in patients with myocardial infarction or in patients with angina pectoris $(P>0.05)$. The serum triglycerides correlated inversely with age in patients with myocardial infarction $(0.01>P>0.001)$, and had no relation to age in 
patients with angina pectoris $(P>0.05)$. This is shown in Fig. I.

Analysis of data obtained from the angiograms showed that the mean score of the anterior descending artery and right coronary artery as well as mean total score was significantly higher in patients with myocardial infarction compared with those with angina pectoris without infarction. This is shown in Table I.

TABLE I Mean score in each main coronary artery and mean total score for patients with myocardial infarction or angina pectoris without infarction

\begin{tabular}{|c|c|c|c|c|c|}
\hline & \multicolumn{2}{|c|}{$\begin{array}{l}\text { Myocardial } \\
\text { infarction } \\
(n=46)\end{array}$} & \multicolumn{3}{|c|}{$\begin{array}{l}\text { Angina pectoris } \\
(n=25)\end{array}$} \\
\hline & Mean & $S D$ & Mean & $S D$ & $P$ \\
\hline \multirow{3}{*}{$\begin{array}{l}\text { Anterior descend- } \\
\text { ing artery } \\
\text { Circumflex artery } \\
\text { Right coronary } \\
\text { artery } \\
\text { Total score }\end{array}$} & $2 \cdot 3$ & 0.77 & $1 \cdot 4$ & 0.95 & $<0.01$ \\
\hline & $I \cdot 7$ & 0.78 & $I \cdot 4$ & $I \cdot 23$ & $>0.05$ \\
\hline & $\begin{array}{l}2 \cdot 0 \\
6 \cdot 0\end{array}$ & $\begin{array}{l}I \cdot 17 \\
I .65\end{array}$ & $\begin{array}{l}I \cdot 4 \\
4 \cdot 2\end{array}$ & $\begin{array}{l}1 \cdot 26 \\
2 \cdot 70\end{array}$ & $\begin{array}{l}0.05-0.01 \\
<0.01\end{array}$ \\
\hline
\end{tabular}

The values for total score related to age are shown in Fig. 2. There was a considerable spread of individual data for total score in all age groups. Total score correlated positively with age in patients with angina pectoris $(0.05>\mathrm{P}>0.0 \mathrm{I})$, and had no

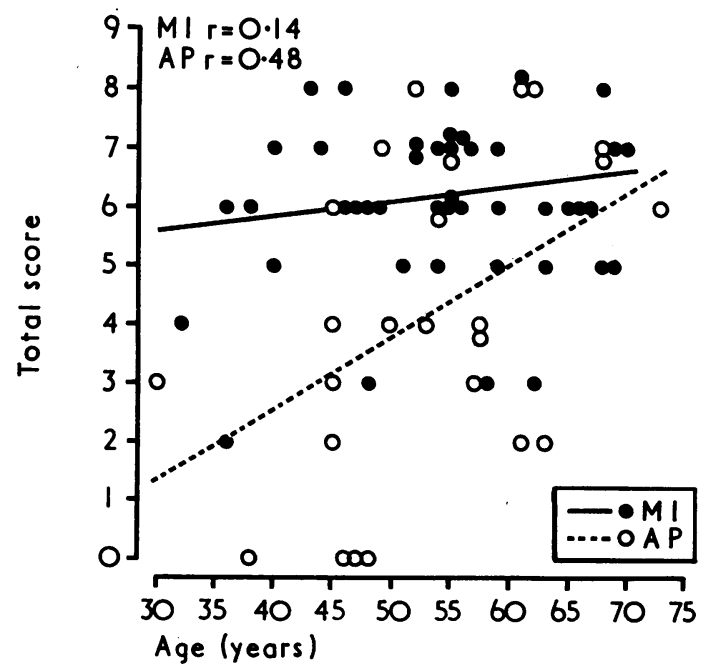

FIG. 2 The relation between age and total coronary arterial score. Symbols and lines as in Fig. I.

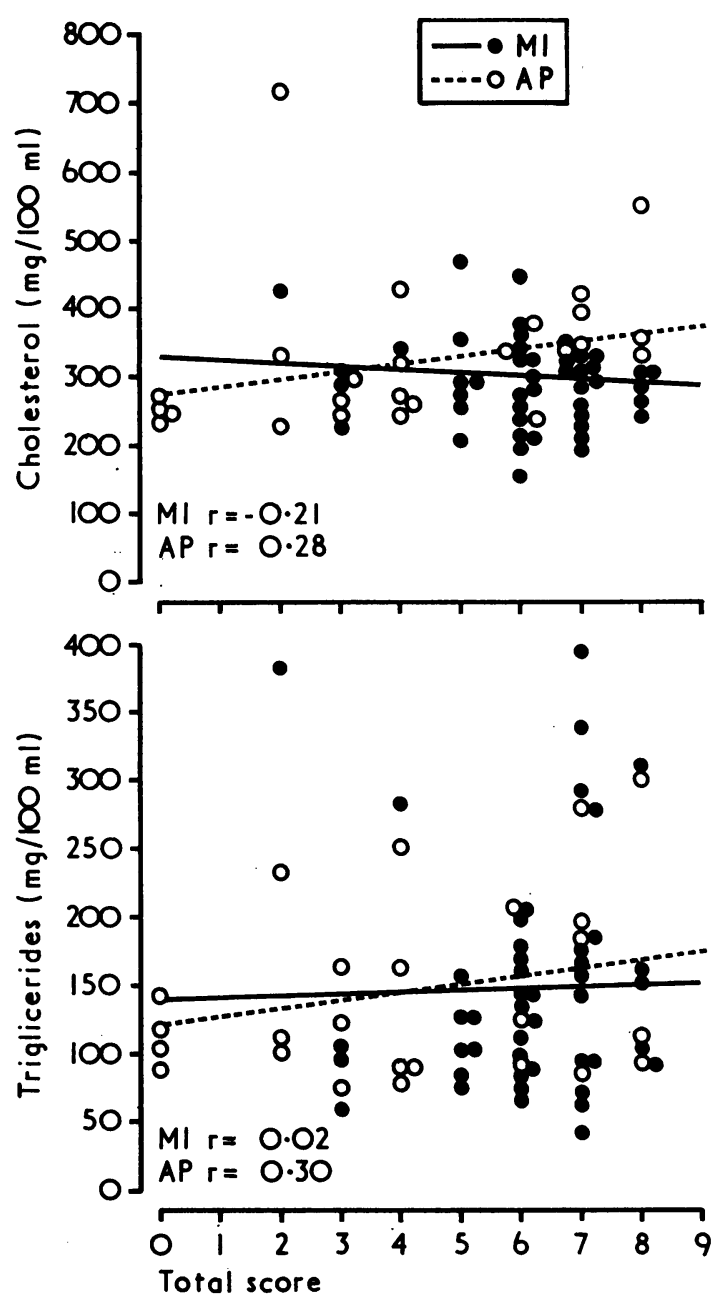

FIG. 3 The relation between total coronary arterial score and serum cholesterol (above) and triglycerides (below). Symbols and lines drawn as in Fig. 1 .

relation to age in patients with myocardial infarction $(\mathbf{P}>0.05)$.

Analysis of the relation between the angiographic findings and individual values for the two serum lipids is shown in Fig. 3 and Fig. 4. No significant correlation was found when total coronary arterial score was correlated to serum cholesterol values or to the triglycerides $(P>0.05)$. In this respect there was not any difference between patients with angina pectoris and patients with myocardial infarction.

To study the role of high levels of both plasma lipids two groups of patients were studied: patients with normal levels of both lipids, and those with an increase of both triglycerides and cholesterol (Table 
2). Though the mean score for all three main arteries as well as the mean total score tended to be somewhat higher in the latter group, the intergroup differences were either insignificant or barely significant.

TABLE 2 Mean score in each main coronary artery and mean total score in relation to values for both serum cholesterol and triglycerides

\begin{tabular}{|c|c|c|c|c|c|}
\hline \multirow[t]{3}{*}{ Group } & \multicolumn{5}{|c|}{ Plasma lipid grade } \\
\hline & \multicolumn{2}{|c|}{$A(n=3 I)$} & \multicolumn{3}{|c|}{$B(n=20)$} \\
\hline & Mean & $S D$ & Mean & $S D$ & $P$ \\
\hline $\begin{array}{l}\text { Anterior descend- } \\
\text { ing artery }\end{array}$ & $\mathrm{I} \cdot 8$ & $I \cdot I 2$ & $2 \cdot 0$ & 0.65 & $>0.05$ \\
\hline $\begin{array}{l}\text { Circumflex artery } \\
\text { Right coronary }\end{array}$ & $I \cdot 4$ & $I \cdot 09$ & $1 \cdot 8$ & $1 \cdot 00$ & $>0.05$ \\
\hline $\begin{array}{l}\text { artery } \\
\text { Total score }\end{array}$ & $\begin{array}{l}I \cdot 5 \\
4 \cdot 6\end{array}$ & $\begin{array}{l}I \cdot 3 I \\
2 \cdot 38\end{array}$ & $\begin{array}{l}2 \cdot 1 \\
5 \cdot 9\end{array}$ & $\begin{array}{l}\mathrm{I} \cdot 07 \\
\mathrm{I} \cdot 80\end{array}$ & $\begin{array}{l}>0.05 \\
0.05-0.01\end{array}$ \\
\hline $\begin{array}{l}\star \text { Cholesterol mg/ } \\
\text { Triglycerides } \mathrm{m}\end{array}$ & $\begin{array}{l}100 \mathrm{ml}: \\
/ 100 \mathrm{ml}\end{array}$ & $\begin{array}{l}\mathrm{A} \\
\leq 30 \\
: \leq 15\end{array}$ & & $\begin{array}{l} \\
300 \\
> \\
150\end{array}$ & \\
\hline
\end{tabular}

\section{Discussion}

In the patients included in the present study, serum cholesterol and triglycerides showed large individual variations, but were in general higher than in normals. The finding of a slight, but statistically not significantly, lower serum cholesterol level in patients with myocardial infarction than in patients with angina pectoris without infarction might indicate a possible difference in dietary habits in the two groups. However, a nearly identical mean value for serum cholesterol was reported by Leren (1966) in his study of men with myocardial infarction before starting a dietary trial. The prematurity of the disease in our younger patients with infarction may be linked to the higher circulating triglycerides seen in these patients. From the published reports it is well recognized that the incidence of ischaemic heart disease is found to increase linearly with increasing fasting concentrations of serum cholesterol and triglycerides; the latter parameter appears to be at least as important as the cholesterol (Kannel et al., 1964; Carlson and Bøttiger, 1972).

In most patients varying degrees of obstructive lesions angiographically localized to one or all main coronary arteries were found. The angiographic findings were typical of coronary atherosclerosis. The structural changes were in particular pronounced in those patients who had a proven history of previous myocardial infarction as compared with the patients with angina pectoris without infarction. In the former group, the left anterior descending artery was most often affected, as also found by other authors (Mitchell and Schwartz, I966; Banks et al., 1971).

It appears from the present study that the degree of structural changes within the coronary arteries in the angina pectoris group was positively correlated to age, while no such relation was found in patients with myocardial infarction. The full significance of these observations is not clear. The lack of correlation between age and structural vascular changes seen in the latter group, however, might indicate a higher mortality rate during the acute phase of the disease in older patients with the most advanced stage of coronary atherosclerosis. Another explanation is that when an infarction has occurred, the atherosclerotic changes are developed to the same extent within all age groups. The positive correlation between the degree of structural changes in the coronary arteries and age found in patients with angina pectoris most probably reflects the wellestablished relation between the progression of atherosclerosis with advancing age. Younger subjects, being more active than elder people, may also more easily experience typical ischaemic pain in spite of relatively small changes in the vessels.

In this study, we failed to confirm any relation between the degree of obstructive lesions verified angiographically and blood lipid levels. This does not necessarily mean that the blood lipids were of no importance in the development of coronary atherosclerosis. From the considerations given above, it is essential to be aware of the fact that dealing with patients with coronary heart disease, the role of the blood lipids for several reasons may be modified to an extent which makes any correlation between these parameters and the obstruction impossible.

\section{References}

Banks, D. C., Raftery, E. B., and Oram, S. (197I). Clinical significance of the coronary arteriogram. British Heart fournal, 33, 863.

Carlson, L. A., and Bøttiger, L. E. (1972). Ischaemic heartdisease in relation to fasting values of plasma triglycerides and cholesterol. Lancet, $\mathbf{1}, 865$

Carr, J. J., and Drekter, I. J. (1956). Simplified rapid technic for the extraction and determination of serum cholesterol without saponification. Clinical Chemistry, 2, 353.

Cramér, K., Paulin, S., and Werkø, L. (1966). Coronary angiographic findings in correlation with age, body weight, blood pressure, serum lipids, and smoking habits. Circulation, 33, 888.

Eliasch, H., Edhag, O., Grepe, A., and Biørck, G. (1967). Contribution of the coronary arteriogram to diagnosis of coronary heart disease. American fournal of Cardiology, 19, 502. 
Judkins, M. P. (1967). Selective coronary arteriography. Part I. A percutaneous transfemoral technic. Radiology, 89, 815.

Kannel, W. B., Dawber, T. R., Friedman, G. D., Glennon, W. E., and McNamara, P. M. (1964). Risk factors in coronary heart disease. Annals of Internal Medicine, 6r, 888.

Lancet (1971). The coronary arteriogram. Editorial. 2, 1297

Laurell, S. (1966). A method for routine determination of plasma triglycerides. Scandinavian fournal of Clinical and Laboratory Investigation, 18, 668.

Leren, P. (1966). The effect of plasma cholesterol lowering diet in male survivors of myocardial infarction, p. 92. Universitetsforlaget, Oslo.

Mitchell, J. R. A., and Schwartz, C. J. (1966). Arterial Disease, p. I06. Blackwell, Oxford.
Nordenstrøm, B. (1964). Coronary angiography. In A clinical and hemodynamic analysis of factors limiting the cardiac performance in patients with coronary heart disease, p. 94 . Ed. by R. O. Malmborg. Acta Medica Scandinavica, Stockholm.

Proudfit, W. L., Shirey, E. K., and Sones, F. M. (1967) Distribution of arterial lesions demonstrated by selective cinecoronary arteriography. Circulation, 36, 54.

Snedecor, G. W. (1956). Statistical Methods, 5th ed., Iowa State College Press, Ames, Iowa.

Requests for reprints to Dr. S. Nitter-Hauge, Medical Department B, University Hospital, Rikshospitalet, Oslo, Norway. 